\title{
Properties of Soils of Abandoned Coal Mine Industrial Areas (Primorsky Krai, Russia)
}

\author{
Olga D. Arefieva, Valentina G. Tregubova, Natalya V. Gruschakova, Valerij T. Starozhilov
}

Far Eastern Federal University, Vladivostok, Russian Federation

Email: arefeva.od@dvfu.ru

How to cite this paper: Arefieva, O.D., Tregubova, V.G., Gruschakova, N.V. and Starozhilov, V.T. (2018) Properties of Soils of Abandoned Coal Mine Industrial Areas (Primorsky Krai, Russia). Journal of Geoscience and Environment Protection, 6, 78-92. https://doi.org/10.4236/gep.2018.66006

Received: April 30, 2018

Accepted: June 19, 2018

Published: June 22, 2018

Copyright $\odot 2018$ by authors and Scientific Research Publishing Inc. This work is licensed under the Creative Commons Attribution International License (CC BY 4.0).

http://creativecommons.org/licenses/by/4.0/

\begin{abstract}
Lipovtsy coal field mine №4 processed north-western reserves of Lipovtsy field in Primorski Krai (Russia). In 1997, the mine was declared unprofitable and was abandoned by natural flooding with no arrangement of mine water discharge and in 2005 it was fully flooded. The main sources of pollution in the studied area are spoil heaps (mine wastes), underspoil filtering waters and mine waters which are being discharged on the surface after finishing of "hydraulic funnel" artificial support. The study of technogenic landscape of abandoned mine industrial area showed that its morphologic form is dominated by spoil heaps. Soils located near mine waste body differ from benchmark soils by chemical properties and size distribution. The influence of active hydrochemical mine and drainage water flows is the reason of the above-mentioned variation in soil properties. Results showed that, there exist a high correlation ratios between chemical composition of mine waters and water extracts from soil: Between the alkalinity of mine waters and electrical conductivity of soil water extracts $(r=0.73)$, between mine water iron content and $\mathrm{pH}$ of soil water extract $(\mathrm{r}=-0.56)$, between the solid residue of mine waters and electrical conductivity of soil water extracts $(r=0.72)$, between the mine waters calcium content and electrical conductivity of soil water extracts $(\mathrm{r}=-0.75)$, between the alkalinity of mine waters and silicon dioxide content of soil water extracts $(r=0.61)$, between the mineralization of mine waters and chrome content of soil water extracts $(r=0.73)$.
\end{abstract}

\section{Keywords}

Luvisols, Gleysols, Spoil Heaps, Abandoned Coal Mines, Heavy Metals

\section{Introduction}

Having started in mid-90s, a massive closure of unprofitable and loss-making 
mines commenced in Russia under a coal industry restructuring program and was weakly supported by regulations and engineering requirements for many kinds of liquidation works. The coal industry-restructuring program, besides closing of specifically loss-making mines, had the objective to improve the environment in coal mining areas. Many scientists and specialists thought that within 2 - 3 years after flooding primeval hydrogeological situation would set, mine waters quality would improve so that would be suitable for drinking purposes; rocks movement, earth surface sedimentation and deformation would stop [1] [2] [3]. However, it appeared to be that upon the closing of unprofitable mines the negative impact grows. Dump masses when storing forms a new relief not typical for this area. Overlapping natural soils by moldboard masses entails a violation of vegetation, often it followed by formation of a secondary anthropogenic cenoses. This phenomenon is observed in a radius from one and a half to two kilometers around the waste dumps [4] [5].

Although structural and man-made changes in the geological massive stop, the other types of negative effects keep on going and some even become more active, for example the level of ground water rises and degradation of soil is observed [1] [6] [7] [8]. In addition, spoil heaps of abandoned mines eroding on the surface are a source of soil pollution with heavy metals $(\mathrm{Ni}, \mathrm{V}, \mathrm{Cu}$, etc.). Quite often rock mass dumps cover soils of adjacent territories, as well as they serve as the cause of acid or alkaline solutions resulting from precipitation washing [4] [9] [10] [11] [12] [13]. The influence area of rock mass dumps may extend up to $300 \mathrm{~m}$ and more. It is at such a distance from waste heaps that allows the concentration of heavy metals in soils.

The issue of abandoned mine waste negative impact on the environment exists not only in Russia, but also in other countries, e.g., China [14], Slovenia [15], USA [16], etc.

However, the most large-scale negative process connected with 'wet' closing of coal mines is the discharge of highly mineralized mine water on the surface [17], [18]. Water content of underground mine openings varies greatly and is connected mainly with openness of Cenozoic and black coal sediments [19]. Discharge of mine waters on the surface is arranged via water discharge technological wells but sometimes seepage of those waters is observed. Mine waters are discharged directly into surface water sources in the impact areas of abandoned coal mines [20] [21] [22].

The composition of mine waters is formed as the result of interaction of underground waters with rocks through contact exchange. They contain mineral, organic and bacteriological pollutants. It was found that flooding of mines causes pollution of drinking water sources in communities around mine waters discharge area. Mine waters affect water in wells, spring wells, ground water catchments that is proved mainly by high mineralization. For example, in China heavy metals content is controlled in water wells near abandoned coalfields. Special attention is paid to cadmium and copper [6] [7] [20] [23] [24] [25] [26] 
[27].

Our research showed that in mine waters of abandoned mine Avangard in Primorski Krai, concentrations of lead, zinc, strontium, molybdenum, copper and mercury exceed the maximum permissible concentration (MPC). A close connection of quality parameters and mine water pollutants with the nearby river water parameters and with the quality of well water used by local communities for water supply was found [28]. Under the impact of mine waters and dump area technoginic flows of dissolved substances, the chemical structure of soil is transformed. $\mathrm{pH}$ of soil changes, in the humic-accumulative horizon sulfides and silicon compounds are seen, in mineral horizons iron, chrome and copper compounds are accumulated [29]. As the result, soil cover adjacent to the dump area is experiencing not only a physical impact as the result of overlapping by moldboard masses, but also a strong influence of mine and underspoil waters contributing to the emergence of reducing conditions, leading to an increase in solubility and hence mobility of many chemical compounds. Restorative processes lead to development of gley soil and this in turn leads to changing in the direction of soil formation. Instead of automorphic non-gley soils, hydromorphic gley soils are formed.

This paper studied the issue of soil transformation of technogenic landscapes of abandoned mine industrial areas using the Lipovetsky Coal Basin as a case study.

Abandoned mine of Lipovetsky Coal Basin was mining the reserves of the north-western part of Lipovetsky field located in the Lower Cretaceous coal bearing capacity structure - Razdolnoe Coal Basin which is located within the interstitial water basin of Sikhote Alin folded system and spurs of East Manchu highland, Sikhote-Alin hydrogeological area [30] (Figure 1). In 1997, the mine was deemed unprofitable and abandoned by natural flooding without controlled discharge of mine water; and in 2005 it was fully flooded. The main sources of pollution and soil transformation in the studied area are spoil heaps, filtering underspoil waters and mine waters discharged on the surface after controlled "hydraulic funnel" stop.

Spoil heaps of enclosing rocks being the primary sources for pollution are formed by rock fragments of Lower Cretaceous coal bearing layer [31]. The rocks mainly consist of aleurolits, argillites and arcose sandstones with black coal bearings and layers. Eluvial thickness of sandstones, aleurolits and argillites, which is soil forming ranges between $1-1.5 \mathrm{~m}$. Size distribution is represented mainly by fractions $\geq 10 \mathrm{~mm}$ which content is always higher than $50 \%$. Low fractions of silt $1 \mathrm{~mm}$ and smaller are present in mine waste at the rate of 14\% $20 \%$. The remaining rocks are referred to $1-10 \mathrm{~mm}$ fraction. The absence of sand and loamy clays in rocks is explained by washout of those fractions by storm rainfall. As a rule, those rocks are easily subjective to erosion washing and quite often debris flow tails are seen near spoil heaps.

Microelement structure of spoil heaps is not studied, there is no data on the 

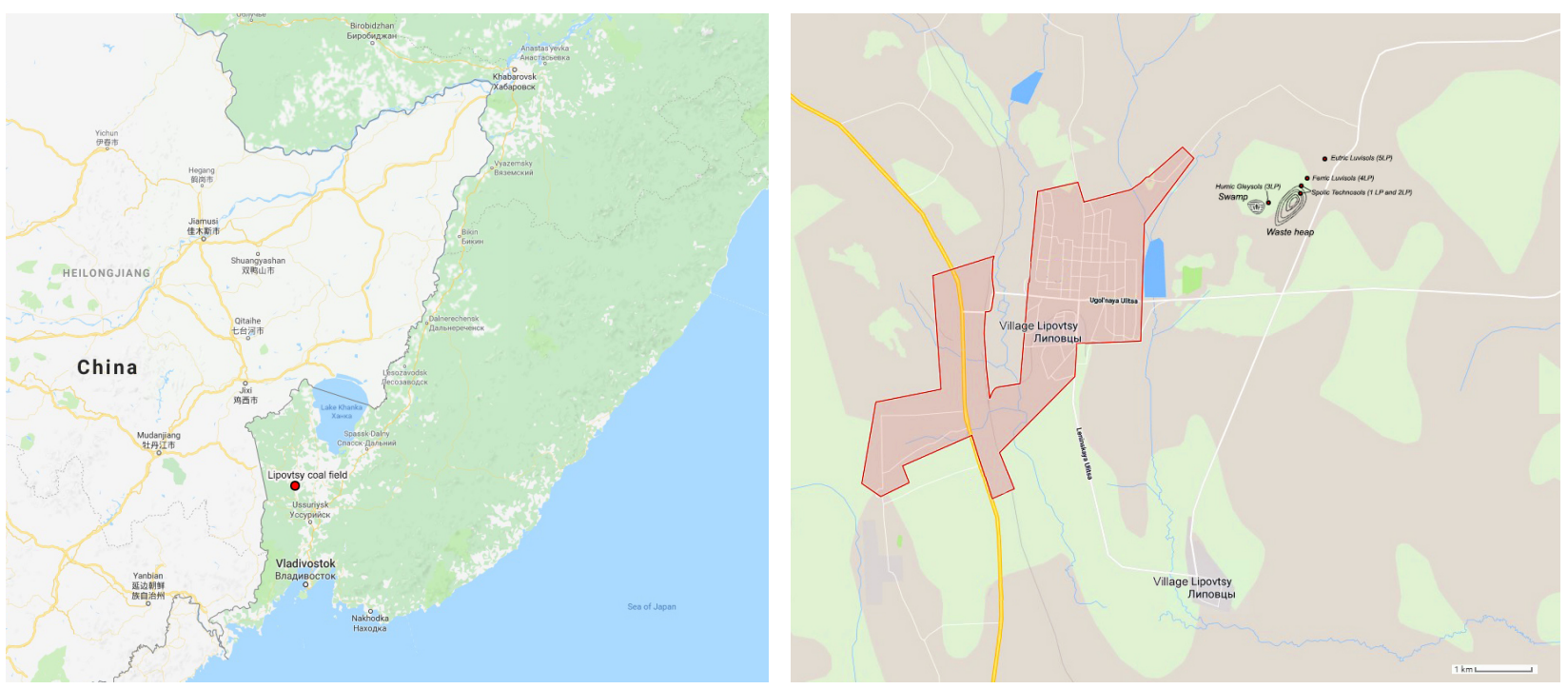

Figure 1. The location the industrial area of the Abandoned mine of Lipovetsky Coal Basin.

composition of macroelements in soil mixtures of spoil heaps. There are only materials available on macro and microelements content in deposit coals. The research by Kitaev showed that maximal content of chemical elements is seen in high-ash coals and this is connected mainly with the accumulation of clastic terrigenous and volcanogenic materials together with organic matter [31].

\section{Material and Methods}

Duplicate samples of mine water, soils and materials of mine waste (1LP, 2LP, 3LP, 4LP, 5LP) were taken in 2011-2013 in autumn and spring seasons in the industrial area of Lipovetsky abandoned mine field. As benchmark soil was taken soil located far from the source of impact (Eutric Luvisols, 5LP). Morphological, chemical, physical-and-chemical properties of soils were determined in compliance with generally accepted soil science methods [32] [33] [34]. The chemical composition of mine waters was studied by core hydrochemical parameters. $\mathrm{pH}$ was determined by a potentiometer using a glass electrode; mineralization was determined by gravimetric method. To determine color, turbidity and total iron content, the photoelectrocolorimetric method was applied using the spectrophotometer UNICO-1201 (USA). Permanganate demand was determined by Skopintsev's method. To determine water hardness and calcium magnesium ions, volumetric titration was applied. Alkalinity was determined by the acidimetric method. Chlorides were determined by the argentometric titration with potassium chromate as indicator, sulfates were determined by complexometry.

Soil-water extracts from specific soil horizons were prepared in compliance with the guideline for soil chemical analysis [32]. The chemical composition of soil-water extracts was determined by spectrophotometry in compliance with the guidelines input in the memory of the portable spectrophotometer DR2700-01B1 
(Hach, Germany). $\mathrm{pH}$ of soil-water extracts was determined by $\mathrm{pH}$-meter FiveEasyPlus 20 (MettlerToledo, Switzerland) and electrical conductivity-by conductometer FiveEasy 30 (MettlerToledo, Switzerland). Statistical analysis of the results of chemical composition of mine waters and soil-water extracts was done with the StatSoft Statistica 10.0 software.

The assessment of heavy metals pollution was based on parallel study of the content of various forms of cadmium, lead and zinc, copper, nickel, etc. in mine waste dumps containing rather large volume of carbonized inclusions as well as in the soils affected by geochemical flows formed in the course of mine waste enleaching by atmospheric rains. The content of cadmium, lead, zinc, copper and nickel in soil profiles and mixed samples of soil top horizons and in layers of mine waste was determined by atomic absorption analysis as per approved guidelines. They were determined acid-soluble forms (5 $\mathrm{M} \mathrm{HNO}_{3}$ ), movable supply forms (extraction by ammonium acetate buffer with $\mathrm{pH} 4.8$ ) and movable water-soluble forms.

\section{Results and Discussion}

\subsection{Characteristics of Luvisols}

The soil surface in the coal mining area of Lipovetsky industrial complex is observed in two forms: Luvisols and Humic Gleysols (Figure 2). Both types of soils are related to the section of differentiated soils texture [35]. They are formed on

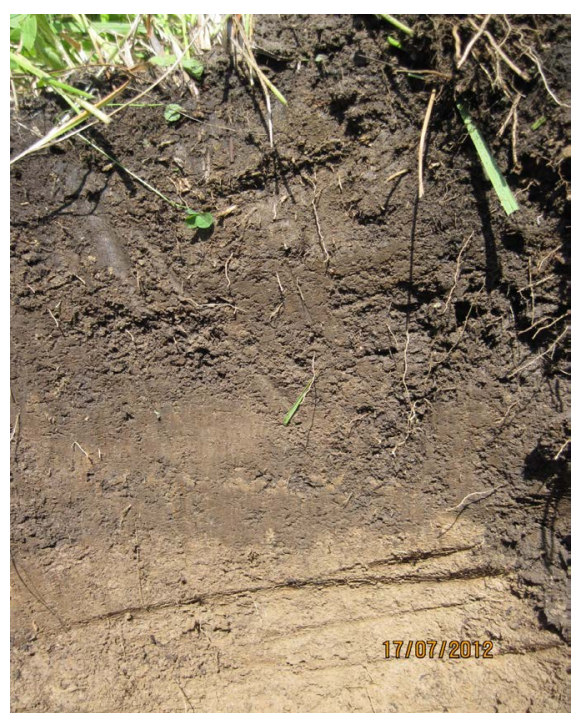

(a)

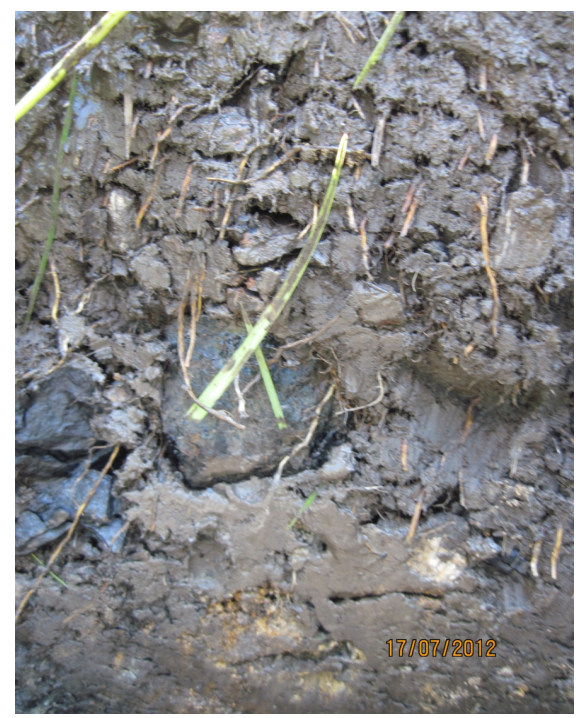

(b)

Figure 2. Morphological soil profile: (a) Luvisols; (b) Humic Gleysols. In the areas located in mine waste direct effect zone, Humic Gleysols are transformed into Ferric Luvisols. The key factors of soils transformation are underspoil and mine waters accumulated in subsidence areas above the developed mine space. They effect the change of soil moisturizing mode causing flooding, over moisture and therefore contributing to development of gleying process. Besides, mechanical inclusions contribute to development of transformation of soils, brought from waste heaps as mud downflow. 
flattened surfaces with herb-bunchgrass cover. The required diagnostic parameter for them is the presence in the profile of the texture horizon together with eluvial horizon, formed due to bleaching of the upper part of texture thickness, gaining light-brown or yellowish color. In both diagnostic horizons there were ferro-manganese noddles. The texture horizon as it has heavy loamy and even clayey granulometric composition, often has the gleying traces in the form of blue-grey and ochreous spots of oxide and ferrous iron. This indicates the ongoing oxidation-reduction process.

\subsection{Chemical Properties of Soils}

The profile of Eutric Luvisols (5LP), which we take as a benchmark is characterized by weak acid medium reaction and not base-saturated soil adsorbing complex (SAC). Among exchangeable bases, calcium dominates accumulated in upper humus accumulation and texture horizons. Usually such distribution of exchangeable calcium is explained by its biogenic accumulation in humus in upper horizon and inside mineral silt with increased content of silt fraction (Table 1).

Table 1. Chemical properties of soils and mine waste of Lipovetsky industrial area.

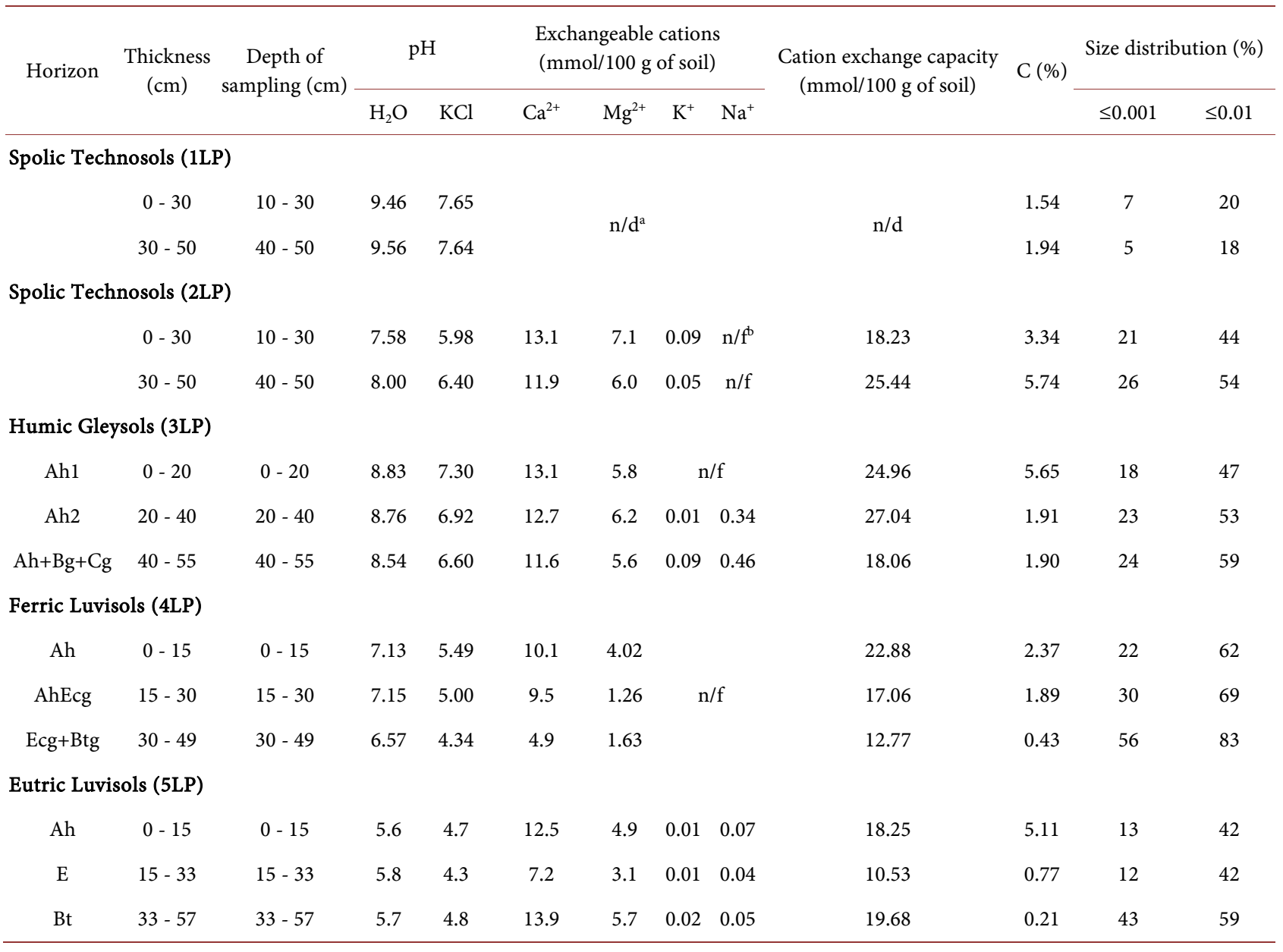

a. Parameter was not being determined. b. Parameter was not being founded. 
The content and distribution of organic carbon by profile is typical for Luvisols-maximum in humus accumulative horizon and sharp drop in underhumus (eluvial). Cation exchange capacity correlates with the parameters of exchangeable bases content as they are mainly determine that value.

The chemical properties of Luvisols are mainly determined by the chemical properties of mine waste effecting them. The waste mixtures of mine waste have alkaline reaction. The alkalinity from hydrocarbonate-ions $\left(\mathrm{HCO}_{3}^{-}\right)$, occurring upon dissolving of calcium carbonates from mine waste rock debris is apparently determinative. Therefore, the reaction of soil medium effected by mine waste is also alkaline. The dependence of the $\mathrm{pH}$ values of these soils on the distance to the "body" of the "body" of a waste heap is obviously seen. The soil profile being close to mine waste (3LP) and much affected by anthropogenic activity, has alkaline reaction of medium. Weakly alkaline and even neutral medium is typical for soils more remote from mine waste (4LP) (Table 1). By the content of exchangeable calcium and magnesium ions in SAC the same dependency is seen-their content in the first profile is lower. Quantitative distribution of organic carbon in the soils studied is orderly-maximum in upper organic horizons that is explained by accumulation of organic carbon in the result of grassy process forming humus-accumulative horizons. Meantime, the effect of mud flows from mine waste containing free carbon should not be minimized. Spolic Technosols (1LP) are characterized by low carbon content while in silt there is some free carbon inclusions visible. Apparently, free carbon abundantly contained in mine waste are gradually undergoing oxidation weathering forming soluble compounds which are washed out by atmospheric rains.

Thus, Luvisols, located near the "body" of a waste heap change not only the morphological properties, but also chemical under the influence of geochemical flows of soluble substances, under the influence of debris flows, as well as under the influence of flooding by underspoil and mine waters. By the re-acquired chemical properties they differ from the butterbur, which we conventionally accepted as the standard. Especially significant are the differences traced on the acid-base properties of soils and particle size distribution, which is understandable, since they first take on the migration flows of soluble compounds and mechanical suspensions.

\subsection{Assessment of Soil Pollution with Heavy Metals}

The above mentioned chemical properties of the soils do not give the full view on the changes occurring inside them. Rocks, buried for a long time beneath the surface are suddenly exposed, the changes in atmospheric conditions leads to intensive weathering. The chemical elements contained in the minerals of those rocks are leached out, forming geochemical flows that have a significant impact on the pollution of soils. The erosion of mine waste creates drifts on soil surface. Because of such a comprehensive geochemical impact of the mine waste and related technogenic flows, the affected soils change not only their natural chemical 
properties but also their chemical composition.

To find the degree of pollution, as well as to determine the nature of contrast of the newly formed characteristics gained by transformed soils, a comparative analysis of the chemical composition of the polluted soils and their non-polluted analogues was made. For that, concentration factors have been calculated for all the forms of heavy metals.

The analysis of the size distribution data of heavy metals content in various objects (Table 2) has shown that mine waste contain increased concentrations of heavy metals, especially zinc, nickel, cadmium, exceeding those in genetic horizons of soils. Therefore, overburden materials is originally enriched with heavy metals being potential pollutants of soils and soil surface. Rather high concentrations of heavy metals have been found in washout zone and redeposit of mine waste materials that occur in Humic Gleysols (3LP) located in direct proximity of mine waste body. Surface horizons of those soils not only inherit high concentrations of a number of elements typical for overburden rocks ( $\mathrm{Zn}, \mathrm{Ni}$, etc.), but become enriched with $\mathrm{Cu}, \mathrm{Pb}, \mathrm{Cr}, \mathrm{Mn}$, the content of which in mine waste is not high. The analysis of $5 \mathrm{M}$ nitric-acid extraction (nominal gross forms of metals) shows that the most intensive deposition of most elements occurs in upper grassy horizon under $20 \mathrm{~cm}$ deep. Exceeding of some metals $(\mathrm{Ni}, \mathrm{Cu}, \mathrm{Pb}$ ) compared to the background is two or more times $(3.8-2.1)$. That acknowledges the fact of accumulation on the soil surface of the materials transferred from the mine waste that has been always enriched with those metals. In addition, accumulation of those elements in the organic matter of organic horizons should not be excluded. The content of $\mathrm{Cu}, \mathrm{Pb}$ in them is $2.1-2.4$ times higher compared to the background. Besides, profile differentiation is seen for lead, maximal content is in mixed layer $(\mathrm{Ah}+\mathrm{Bg}+\mathrm{Cg})$, which is characterized by heavier size of silt.

In the soils not covered by technogenic materials (more remote from the source of impact) $4 \mathrm{LP}$ a lower degree of pollution is observed. Compared to the background soils they contain insignificant exceeding in the content of all heavy metal forms (Table 2). For example, by the content of nominal gross forms of metals the exceeding is one to one and half times, while for some of them $(\mathrm{Cu}$, $\mathrm{Zn}$ ) negative values have been seen, but only in lower horizons of soil profile.

In the soils not covered by technogenic materials (more remote from the source of impact) 4LP a lower degree of pollution is observed. Compared to the background soils they contain insignificant exceeding in the content of all heavy metal forms (Table 2). For example, by the content of nominal gross forms of metals the exceeding is one to one and half times, while for some of them $(\mathrm{Cu}$, $\mathrm{Zn}$ ) negative values have been seen, but only in lower horizons of soil profile.

Movable water-soluble forms of heavy metals in the studied soils are not of any reasonable concern. Firstly, they are insignificant in absolute values; secondly, most often no exceeding is seen by concentration factors.

Thus, the soils associated with the mine waste not only inherit high concentrations 
Table 2. Content of various forms of heavy metals in soils of Lipovetsky industrial area, $\mathrm{mg} \cdot \mathrm{kg}^{-1}$.

\begin{tabular}{lllllllllllllllllll}
\hline Horizon & Thickness $(\mathrm{cm})$ & Depth of sampling $(\mathrm{cm})$ & $\mathrm{Cu}$ & $\mathrm{Zn}$ & $\mathrm{Ni}$ & $\mathrm{Cr}$ & $\mathrm{Mn}$
\end{tabular}

Spolic Technosols (1LP)

Nominal gross forms (5 $\left.\mathrm{M} \mathrm{HNO}_{3}\right)$

$\begin{array}{lllllllll}0-30 & 10-30 & 20.72 & 187.79 & 34.22 & 12.78 & 0.03 & 8.20 & 307.70 \\ 30-50 & 40-50 & 22.28 & 171.44 & 33.84 & 10.27 & 0.10 & 8.44 & 447.10\end{array}$

Movable forms (ammonium acetate buffer)

$\begin{array}{llllllllr}0-30 & 10-30 & 1.07 & 25.89 & 2.10 & 1.73 & 0.07 & 0.87 & 67.29 \\ 30-50 & 40-50 & 1.26 & 27.31 & 2.43 & 1.31 & 0.04 & 0.84 & 72.87\end{array}$

Movable forms (water soluble)

$$
\begin{aligned}
& 0-30 \\
& 30-50
\end{aligned}
$$

Humic Gleysols (3LP)

Nominal gross forms $\left(5 \mathrm{M} \mathrm{HNO}_{3}\right)$

$\begin{array}{lll}\text { Ah1 } & 0-20 & 0-20 \\ \text { Ah2 } & 20-40 & 20-40\end{array}$

$\mathrm{Ah}+\mathrm{Bg}+\mathrm{Cg}$

$40-55$

$40-55$

Movable forms (ammonium acetate buffer)

$\begin{array}{ccc}\text { Ah1 } & 0-20 & 0-20 \\ \text { Ah2 } & 20-40 & 20-40\end{array}$

Movable forms (water soluble)

$\begin{array}{cc}\text { Ah1 } & 0-20 \\ \text { Ah2 } & 20-40 \\ \mathrm{Ah}+\mathrm{Bg}+\mathrm{Cg} & 40-55\end{array}$

Ferric Luvisols (4LP)

Nominal gross forms $\left(5 \mathrm{M} \mathrm{HNO}_{3}\right)$

$\begin{array}{cc}\text { Ah } & 0-15 \\ \text { AhEcg } & 15-30 \\ \text { Ecg }+ \text { Btg } & 30-49 \\ & \end{array}$

$\begin{array}{ccccccrrrrrr}\text { Ah } & 0-15 & 0-15 & 0.17 & 0.81 & 0.59 & 0.75 & 0.01 & 0.26 & 18.85 \\ \text { AhEcg } & 15-30 & 15-30 & 0.04 & 1.86 & 0.67 & 1.02 & 0.02 & 0.36 & 18.40 \\ \text { Ecg + Btg } & 30-49 & 30-49 & 0.13 & 0.36 & 0.96 & 1.03 & <0,005 & 0.26 & 13.58\end{array}$

\begin{tabular}{|c|c|c|c|c|c|c|c|c|c|}
\hline $\mathrm{Ah}$ & $0-15$ & $0-15$ & 0.03 & 0.11 & 0.08 & $<0.005$ & $<0.005$ & 0.02 & 0.19 \\
\hline AhEcg & $15-30$ & $15-30$ & 0.04 & 0.28 & 0.04 & $<0.005$ & $<0.005$ & 0.02 & 0.13 \\
\hline $\mathrm{Ecg}+\mathrm{Btg}$ & $30-49$ & $30-49$ & 0.02 & 0.07 & 0.06 & $<0.005$ & $<0.005$ & 0.003 & 0.11 \\
\hline
\end{tabular}

Movable forms (water soluble) 


\section{Continued}

Eutric Luvisols (5LP)

Nominal gross forms $\left(5 \mathrm{M} \mathrm{HNO}_{3}\right)$

$\begin{array}{cccccccccc}\text { Ah } & 0-15 & 0-15 & 21.5 & 171.30 & 5.30 & 50.40 & 0.08 & 13.90 & 2524.80 \\ \text { E } & 15-33 & 15-33 & 12.4 & 86.00 & 12.50 & 8.80 & <0.005 & 13.90 & 278.50 \\ \text { Bt } & 33-57 & 33-57 & 14.6 & 91.70 & 11.90 & 7.50 & <0.005 & 12.10 & 198.90\end{array}$

Movable forms (ammonium acetate buffer)

$\begin{array}{cccccccccc}\text { Ah } & 0-15 & 0-15 & 0.37 & 6.30 & 0.35 & 2.10 & 0.03 & 0.16 & 31.06 \\ \mathrm{E} & 15-33 & 15-33 & 0.20 & 1.50 & 0.08 & 0.90 & <0.005 & 0.29 & 12.24 \\ \mathrm{Bt} & 33-57 & 33-57 & 0.19 & 0.98 & 0.05 & 0.54 & <0.005 & 0.11 & 12.56\end{array}$

Movable forms (water soluble)

\begin{tabular}{ccccccccccc} 
Ah & $0-15$ & $0-15$ & 0.06 & 0.18 & 0.06 & $<0.005$ & $<0.005$ & 0.01 & 0.13 \\
E & $15-33$ & $15-33$ & 0.04 & 0.15 & 0.01 & 0,01 & $<0.005$ & 0.04 & 0.09 \\
$\mathrm{Bt}$ & $33-57$ & $33-57$ & 0.03 & 0.12 & 0.01 & $<0.005$ & $<0.005$ & 0.02 & 0.09 \\
\hline
\end{tabular}

of a number of chemical elements but also in the result of transformation (chemical differentiation) occur to be polluted by heavy metals. Pollution of soil with heavy metals is made not only with solutions discharged from mine waste and not only with coarse dispersion being technogenic drifts but also because of flooding with mine and underspoil water. Upon such a comprehensive effect, soils drastically change their natural characteristics and chemical composition. Analytical materials of soil water extracts, mine and underspoil water evidence this.

As seen from Figure 3, the decrease of $\mathrm{pH}$, electrical conductivity and $\mathrm{Cr}(\mathrm{VI})$ content is observed from mine waste to Eutric Luvisols. $\mathrm{pH}$ is evenly changing from weakly alkaline (point 1 ) area to neutral (point 5). By electrical conductivity, the statistical differences between Spolic Technosols and Luvisols have not been observed (points 1-4). The differences have been detected only between those points (1-4) and Eutric Luvisols (point 5), which evidences salinization (contamination) of the soils close to the mine waste. By $\mathrm{Cr}(\mathrm{VI})$ content, there are differences between Spolic Technosols (point 1) and Eutric Luvisols (point 5) while there are no differences between Spolic Technosols and Luvisols. Meantime, it is seen that $\mathrm{Cr}(\mathrm{VI})$ is being accumulated in soil under effect of mine waste but due to large spread of values in points 2-4 they are statistically not different from Eutric Luvisols (point 5).

Table 3 includes the coefficients of correlation between the chemical composition of soil water extract and mine water of the abandoned mine № 4 of Lipovtsy community. As seen from the table, growing mineralization and permanganate demand of mine water may cause accumulation of chrome compounds and increase of conductivity in soil solution. Growing alkalinity also contributes to accumulation of silicon compounds in soil solution and its 

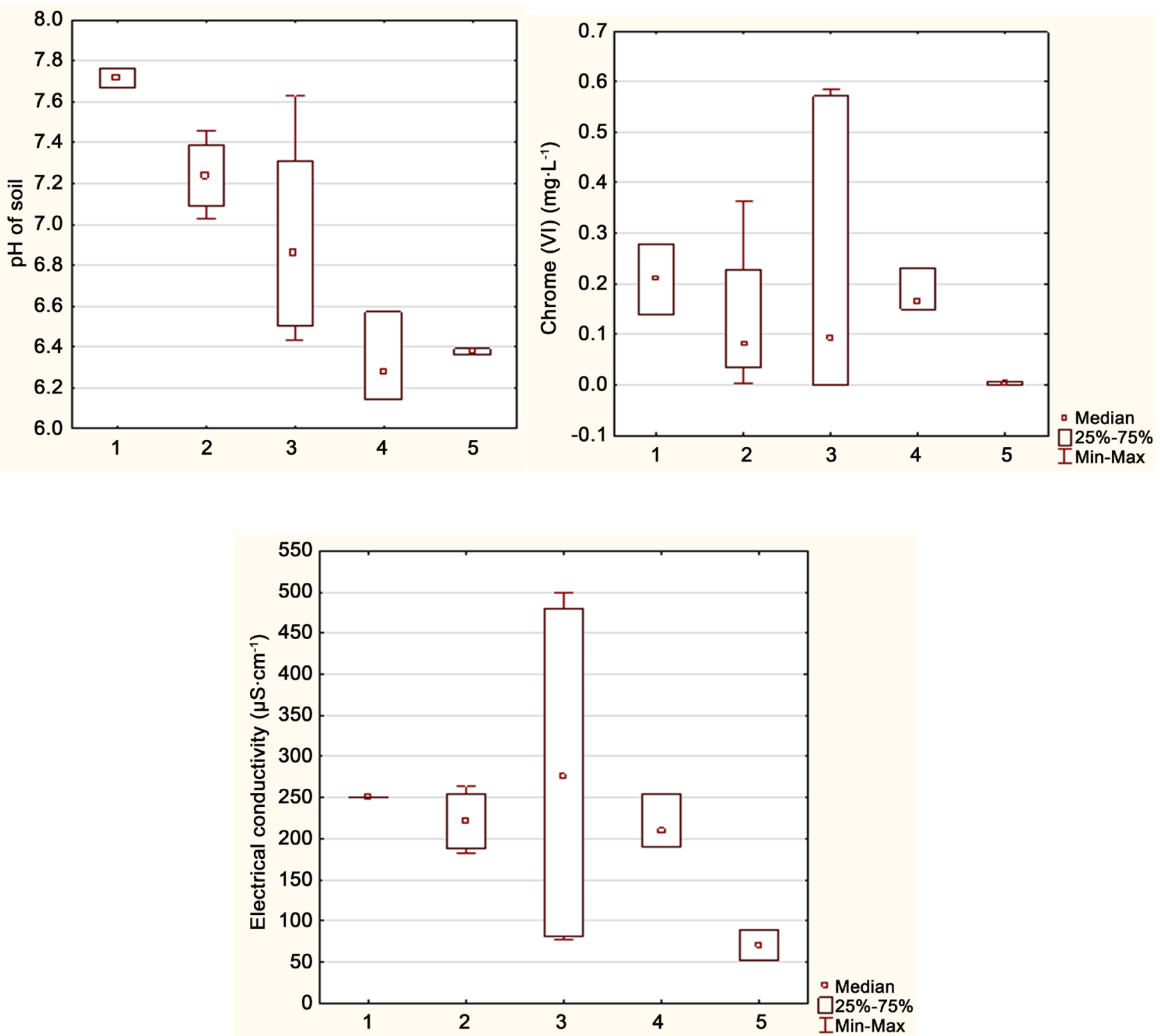

Figure 3. Chemical composition of water extracts of Spolic Technosols, Eutric Luvisols and Luvisols of mine Lipovtsy community (South well): 1 (1LP), 2 (2LP)—Spolic Technosols; 3 (3LP), 4 (4LP)-Luvisols; 5 (5LP)_Eutric Luvisols.

Table 3. Coefficients of correlation between the chemical composition of soil water extract and mine water of the abandoned mine of Lipovtsy community $(\mathrm{N}=13, \mathrm{p}<0.05)$.

\begin{tabular}{|c|c|c|c|c|}
\hline Soil extract Mine water & Chrome (VI) (mg.L-1 $\left.{ }^{1}\right)$ & Silicon dioxide $\left(\mathrm{mg} \cdot \mathrm{L}^{-1}\right)$ & Electrical conductivity $\left(\mu \mathrm{S} \cdot \mathrm{cm}^{-1}\right)$ & $\mathrm{pH}$ \\
\hline Solid residue $\left(\mathrm{mg} \cdot \mathrm{L}^{-1}\right)$ & 0.64 & ${ }^{\mathrm{a}}$ & 0.72 & - \\
\hline Mineralization $\left(\mathrm{mg} \cdot \mathrm{L}^{-1}\right)$ & 0.64 & - & 0.63 & - \\
\hline $\mathrm{PD}\left(\mathrm{mgO} \cdot \mathrm{L}^{-1}\right)$ & 0.60 & - & 0.68 & - \\
\hline Alkalinity $\left(\mathrm{mmol} \cdot \mathrm{L}^{-1}\right)$ & - & 0.61 & 0.73 & - \\
\hline $\mathrm{Ca}^{2+}\left(\mathrm{mg} \cdot \mathrm{L}^{-1}\right)$ & - & -0.58 & -0.75 & - \\
\hline Total iron $\left(\mathrm{mg} \cdot \mathrm{L}^{-1}\right)$ & - & - & - & -0.56 \\
\hline
\end{tabular}

a. No association. 
conductivity increase. Hardness salts conversely decrease the mobility of silicon compounds and the electric conductivity.

Regression analysis between the content of total iron in mine water and $\mathrm{pH}$ of soil water extract, mineralization of mine water and chrome content in soil water extract is showing close interrelation between the said parameters. Growth of iron concentration in mine water may cause acidification of soil solution and mineralization may cause accumulation of chrome compounds (Figure 4).

Positive dependency may be seen between the alkalinity of mine water and the content of silicon compounds and the electric conductivity of soil solutions and that is possibly associated with the solution of soil silicates in alkaline media (Figure 5).
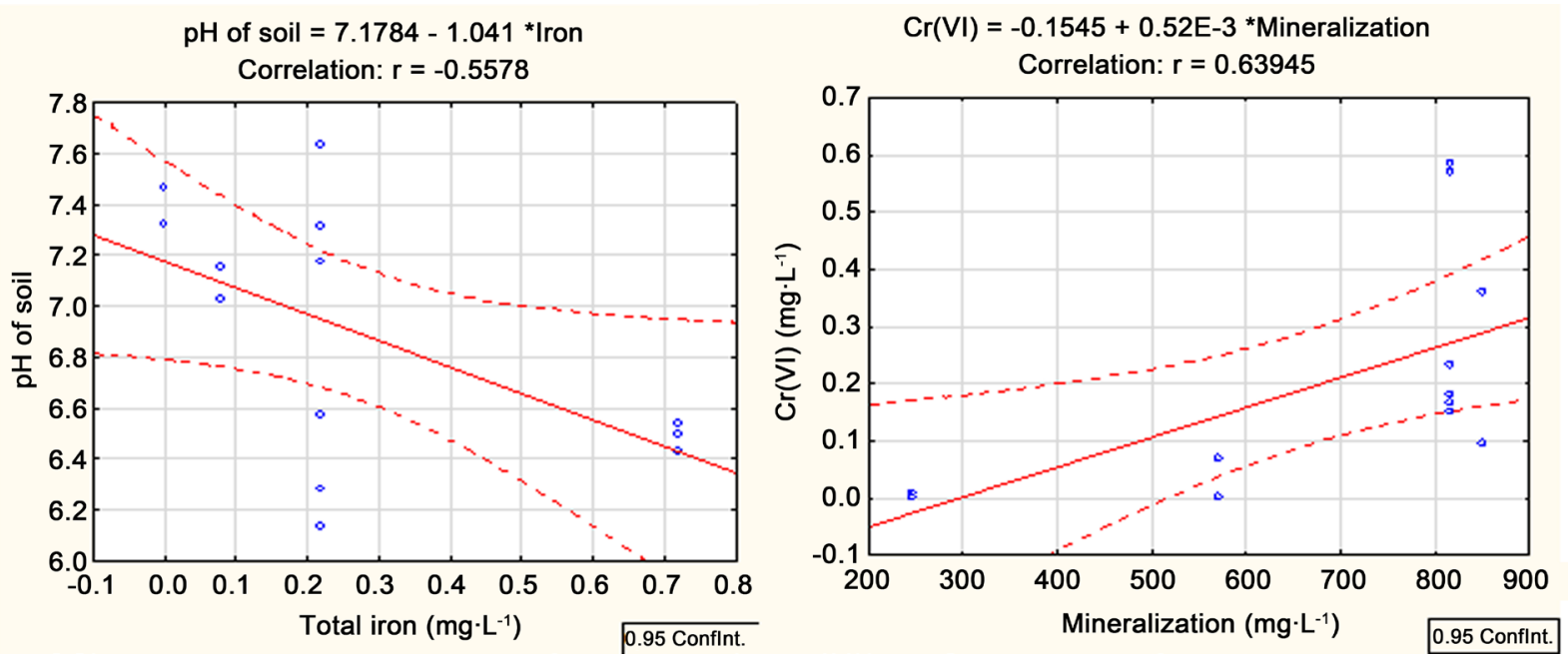

Figure 4. Regression curve of the dependency of $\mathrm{pH}$ and chrome content in soil extract on total iron content and mineralization in mine water.
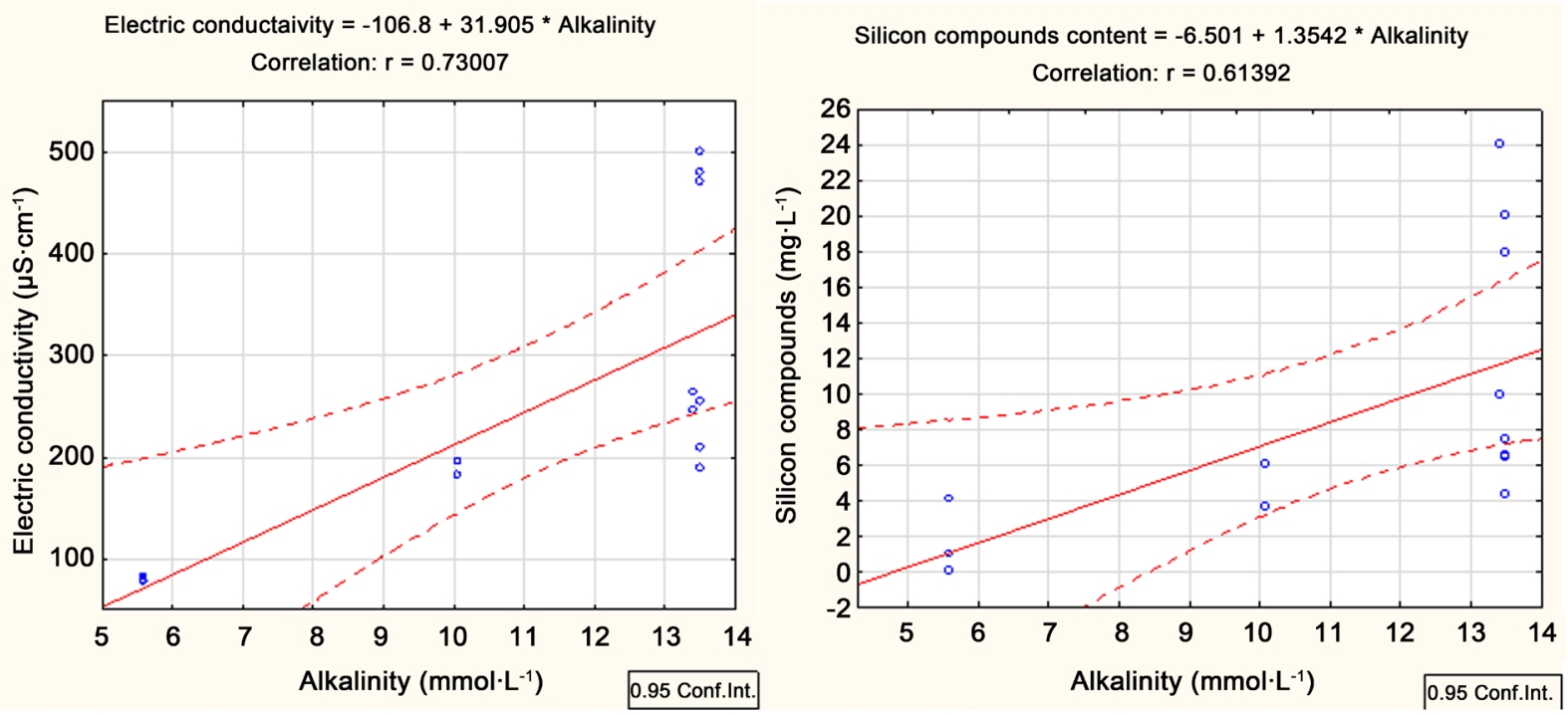

Figure 5. Regression curve of the dependency of electrical conductivity and silicon compounds content in soil extract on alkalinity of mine water. 
Thus, the dependencies obtained show that continuous discharge of rather active hydrochemical flows of mine and filtering water causes changes in the properties of soils under the sphere of their impact.

\section{Conclusions}

The morphological view on the industrial zone of abandoned mine № 4 of Lipovtsy (South well) is determined by mine waste which changes the terrain effecting the formation of secondary anthropogenic cenosis and are the source of technogenic geochemical flows affecting soil. Spolic Technosols being a part of the technogenic flow may be deposited on the soil surface causing not only pollution with chemical elements many of which are from heavy metals group and also causing soils transformation. As the result, Luvisols close to mine waste are exposed to its impact in the form of geochemical flows of soluble matters, mud flows and flooding with underspoil and mine waters are by their chemical properties different from Eutric Luvisols.

The soils not covered by technogenic materials (more remote from the source of pollution) are less exposed to pollution and transformation and have less differences compared to Eutric Luvisols. They contain insignificant exceeding of all heavy metals content. It was found that the pollution impact on the soil with heavy metals is carried out not only with the solutions discharged from mine waste, and not only due to coarse dispersion being basically technogenic drifts but also as the result of soil flooding with mine and underspoil water.

The availability of geochemically active compounds inside technogenic drifts capable for an easy transformation into a solution as well as for a continuous discharge of rather active hydrochemical flows of mine and filtering water causes changes in the properties of soils under the sphere of their impact. The decrease of $\mathrm{pH}$, electrical conductivity and $\mathrm{Cr}(\mathrm{VI})$ content is observed from mine waste to Eutric Luvisols. Close correlation was found between the chemical structure of mine waters and the soil solution.

\section{References}

[1] Golovko, I.V. (2004) Problems of Environmental Effect by Mass Flooding of Coal Mines. Mining Information and Analysis Bulletin (Scientific and Technical Journal), 6, 148-150.

[2] Zakrutkin, V.E., Nikanorov A.M, Reshetnyak O.S., Gubkov E.V. and Sklyarenko, G.Yu. (2017) Main Hydroecological Problems of Coal-Producing Regions. Water Resources: New Challenges and Solutions: Collection of Scientific Works Dedicated to the Year of Ecology in Russia and the 50th Anniversary of the Institute of Water Problems, Russian Academy of Sciences, Sochi, 2-7 October 2017, 358-362.

[3] Molev, M.D. Zanina, I.A. and Stuzhenko, N.I. (2017) Scientific and Methodical Bases of Planning of Ecologically Safe Actions for Elimination of Coal Mines. Mining Information and Analytical Bulletin (Scientific and Technical Journal), 1, 138-145.

[4] Shuvalov, Yu.V., Nifontova, T.I. and Ekgard, V.V. (2003) Processing Solid Wastes 
of Coal Mining and Enrichment in Pechora Basin as a Step to Protect Environment. Mining Information and Analytical Bulletin (Scientific and Technical Journal), 7, 95-98.

[5] Kachurin, N.M., Vasilyev, P.V., Rybak, V.L. and Bogdanov, S.M. (2015) Environmental Consequences of Coal Mine Closure, Tula State University, Tula.

[6] Kurakov, Yu.I., Kukhtin, V.N. and Suvorov, V.G. (2004) Impact of Mines Closing on the Environment of Mining Towns and Communities. Mining Information and Analysis Bulletin (Scientific and Technical Journal), 4, 123-124.

[7] Krechetova, E.A. and Iofis, M.A. (2011) Ecological Consequences of Liquidation of Coal Mines in Eastern Donbass. Scientific Bulletin of Moscow State Mining University, 11, 35-40.

[8] Tarasenko, I.A., Chepkaya, N.A., Elistafenko, T.N., Zinkov, A.V., Kataeva, I.V. and Sadardinov, I.V. (2004) Ecological Consequences of Coal Mines Closing and Steps to Prevent Their Negative Regional Impact. Bulletin of Far Eastern branch of RAS, 1, 87-93.

[9] Harchenko, V.V. (2012) Factors Contributing to Ways of Development and Use of Coal Containing Wastes of Eastern Donbass. Scientific Bulletin of Moscow State Mining University, 9, 92-97.

[10] Levkin, N.D. and Mukhina, N.E. (2011) Impact of Rock Wastes of Coal Mines on Environment Condition. Actual Problems of Humanitarian and Natural Sciences, 5, 277-279.

[11] Levkin, N.D., Kalaeva, S.Z., Rybak, V.L. and Bogdanov, S.M. (2016) Methodical Regulations of the Complex Assessment of Impact of Rock Dumps of Mines on Environment. Bulletin of Tula state University. Earth Science, 1, 43-52.

[12] Kharionovsky, A.A. and Danilova, M.Y. (2017) Reclamation of Disturbed Lands in the Coal Industry. Bulletin of the Scientific Center for Safety in the Coal Industry, 3, 72-77.

[13] Kharionovsky, A.A. and Danilova, M.Y. (2017) Problems of Waste Production in the Coal Industry and Ways of Their Solution. Ecology of Industrial Production, 3, $2-7$.

[14] Liao, B., Huang, L.N., Ye, Z.H., Lan, C.Y. and Shu, W.S. (2007) Cut-Off Net Acid Generation $\mathrm{pH}$ in Predicting Acid-Forming Potential in Mine Spoils: Reproduced from Journal of Environmental Quality: Published by ASA, CSSA, and SSSA, 887-891.

[15] Budkovic, T., Sajn, R. and Gosar, M. (2003) Environmental Impact of Active and Abandoned Mines and Metal Smelters in Slovenia. GEOLOGIJA, 46/1, 135-140. https://doi.org/10.5474/geologija.2003.014

[16] Zielinski, R.A., Otton, J.K. and Johnson C.A. (2001) Sources of Salinity Near a Coal Mine Spoil Pile, North-Central Colorado. Journal of Environmental Quality, 30, 1237-1248. https://doi.org/10.2134/jeq2001.3041237x

[17] Lisutina, L.A., Ganicheva, Z. and Pavlov, A.V. (2012) Assessment of Condition of Eastern Donbass's Natural Objects. Don Engineering Bulletin, 3, 833-835.

[18] Zakrutkin, V.E., Gubkov, E.V., Sklyarenko, G.Y. and Reshetnyak, O.S. (2016) Comparative Estimation of Quality of Surface and Underground Waters of the Eastern Donbass by Hydrochemical Indicators. Bulletin of Higher Educational Institutions. The North Caucasian Region. Series. Natural Sciences, 2, 91-99.

[19] Legostaev, S.O. (2011) Development of System of Environmental Measures in Liquidated Mines Area in Eastern Donbass. Mining Information and Analytical Bul- 
letin (Scientific and Technical Journal), 1, 276-281.

[20] Tarasenko, I.A. (2010) On Condition of Environment in Liquidated Mines Areas (Taking Partizansk District of Primorsk Krai as an Example). Bulletin of Far Eastern Branch of RAS, 3, 113-118.

[21] Molev, M.D. and Merkulova, M.A. (2013) Management of Ecological Safety of the Region at the Stage of Liquidation of Coal Mines. Scientific Bulletin of the Moscow State Mining University, 7, 56-62.

[22] Babayan, G.G., Zakrutkin, V.E., Reshetnyak, O.S. and Saakyan, G.A. (2017) Hydrochemical Peculiarities of the Rivers of Armenia Depending on the Altitude Zoning of Landscapes and Types of Nature Use in their Basins. Bulletin of Higher Educational Institutions. The North Caucasian Region. Series. Natural Sciences, 2, 75-83

[23] Chen, A., Lin, C., Lu, W., Wu, Y., Ma, Y., Li, J. and Zhu, L. (2007) Well Water Contaminated by Acidic Mine Water from the Dabaoshan Mine, South China: Chemistry and Toxicity. Chemosphere, 70, 248-255.

https://doi.org/10.1016/j.chemosphere.2007.06.041

[24] Arefieva, O.D., Zemnukhova, L.A. and Yazynina, E.V. (2011) Toxic Metals in Mine Waters of Abandoned Coal Mines of Partizansk City. Bulletin of Far Eastern Branch of $R A S, 5,119-122$

[25] Popova, D.S. (2017) Environmental Problems of Coal Mining Regions of Russia. International Journal of Applied and Fundamental Research, 8, 126-131.

[26] Gavrishin, A.I., Borisova, V.E. and Toropova, E.S. (2017) Modern Features of Formation of Chemical Composition of Mine Waters in Eastern Donbass. Advances in Current Natural Sciences, 7, 59-63.

[27] Zakrutkin, V.E. and. Gubkov E.V. (2016) Mining-Induced Geochemical Flows of Coal Mining Areas and Their Impact on the Environment (on the Example of the Donets Basin). Bulletin of Higher Educational Institutions. The North Caucasian Region. Series: Natural Sciences, 3, 66-71.

[28] Nazarkina, A.V., Arefieva, O.D., Kadyrova, T.M., Buyanova, L.G. and Savenkova E.M. (2013) Impact of Mine Waters of Abandoned Coal Mine "Avangard" on the Environment. Advanced Materials Research, 807-809, 158-161. https://doi.org/10.4028/www.scientific.net/AMR.807-809.158

[29] Arefieva, O.D., Nazarkina, A.V., Gruschakova, N.V. and Sidorova, D.V. (2014) Impact of Waste Coal on Chemical Composition of Soil Solutions in Industrial Areas of Abandoned Coal Mines (Evidence from Avangard Mine, South of the Russian Far East). Applied Mechanics and Materials, 448-453, 402-405.

[30] Primorsk Krai (2004) In Hydrogeology of the USSR. Nedra Publishing, Moscow.

[31] Kitaev, I.V. (1989) Ash-Forming and Small Elements of Far East's Coals: Monograph. FEB of AS of the USSR Publishing, Vladivostok.

[32] Arinushkina, E.V. (1970) Guideline for Chemical Analysis of Soils. MSU Publishing, Moscow.

[33] (1975) Argochemical Methods of Soils Study. Nauka Publishing, Moscow.

[34] GOST 12536-79 (1980) Soils. Methods of Laboratory Granulometric (Grain-Size) and Microaggregate Distribution. Moscow.

[35] Shishov, L.L., Tonkonogov, V.D., Lebedev, I.I. and Gerasimova M.I. (2004) Classification and Diagnostics of Russia's Soils. Oikumena Publishing, Smolensk. 